JURNAL RISET MAHASISWA AKUNTANSI

http://ejournal.unikama.ac.id/index.php/jrma

JRMA, Volume 7, No 2, Oktober 2019

\title{
PENGARUH UKURAN PERUSAHAAN DAN STRUKTUR MODAL TERHADAP NILAI PERUSAHAAN DENGAN DEWAN KOMISARIS INDEPENDEN SEBAGAI VARIABEL MODERASI
}

\author{
Karolina Yunita Dir \\ e-mail:nitadir07@gmail.com
}

\author{
Abdul Halim \\ Rita Indah Mustikowati \\ Program Studi Akuntansi, Fakultas Ekonomika dan Bisnis Universitas Kanjuruhan, Malang
}

\begin{abstract}
ABSTRAK
Penelitian ini bertujuan untuk menjelaskan dan menguji bagaimana pengaruh ukuran perusahaan dan struktur modal terhadap nilai perusahaan dengan dewan komisaris independen sebagai variabel moderasi pada perusahaan perbankan yang terdaftar di Bursa Efek Indonesia periode tahun 2016-2017. Jenis penelitiannya adalah explanatory research, yaitu dengan menggunakan asumsi klasik, menggunakan analisis regresi moderasian, dan menggunakan uji t. Jumlah sampel sebanyak 39 perusahaan, dan untuk metode pengambilan sampel yaitu menggunakan purposive judgment sampling. Variabel dalam penelitian ini terdiri dari ukuran perusahaan dan struktur modal sebagai variabel independen, nilai perusahaan sebagai variabel dependen dan dewan komisaris independen sebagai moderasi. Hasil analisisnya adalah bahwa secara parsial ukuran perusahaan berpengaruh terhadap nilain perusahaan, struktur modal berpengaruh terhadap nilai perusahaan, dewan komisaris independen memperkuat pengaruh ukuran perusahaan terhadap nilai perusahaan dan dewan komisaris independen memperkuat pengaruh struktur modal terhadap nilai perusahaan.

Kata kunci - Ukuran Perusahaan, Struktur Modal, Dewan Komisaris Independen, dan Nilai Perusahaan.
\end{abstract}

\begin{abstract}
This study aims to explain and test how the influence of company size and capital structure on firm value with an independent board of commissioners as a moderating variable in banking companies listed on the Indonesia Stock Exchange in the period 2016-2017. This type of research is explanatory research, namely by using classical assumptions, using moderated regression analysis, and using the t test. The number of samples is 39 companies, and the sampling method is using purposive judgment sampling. The variables in this study consisted of company size and capital structure as an independent variable, company value as the dependent variable and the independent board of commissioners as moderation. The result of the analysis is that partially the size of the company affects the value of the company, the capital structure influences the value of the company, the independent board of commissioners strengthens the influence of the size of the company on the value of the company and the independent board of commissioners strengthens the effect of the capital structure on the value of the company.
\end{abstract}

Keynotes - company size, capital structure, independent board of commissioners, and firm value.

Copyright @ JRMA 2019 ISSN. 2337-5663

Hal | 1 


\section{PENDAHULUAN}

Bank merupakan perantara antara masyarakat dan modalnya, baik masyarakat yang memiliki kelebihan modal ataupun kekurangan modal. Tujuan bank adalah untuk memaksimumkan kemakmuran pemegang saham yaitu dengan cara memaksimalkan nilai perusahaan. Nilai suatu perusahaan secara maksimum dapat memberikan kemakmuranya pada pemegang saham, apabila harga saham dari perusahaan tersebut meningkat. Penambahan jumlah ekuitas perusahaan dengan hutang perusahaan merupakan cara untuk melihat nilai perusahaan.

Ukuran perusahaan adalah faktor yang memberikan pengaruh terhadap nilai perusahaan adalah. Dewi dan Ari, (2013) mengatakan ukuran suatu perusahaan dianggap memiliki pengaruh terhadap nilai suatu perusahaan dikarenakan semakin besar ukuran perusahaan, maka akan lebih mudah perusahaan tersebut mengontrol dan mendapatkan sumber pendanaan, baik itu dari dalam ataupun dari luar perusahaan. Tidak hanya itu, faktor yang juga dapat memberikan pengaruh terhadap nilai perusahaan adalah struktur modal. Struktur modal merupakan perbandingan antara modal asing dan modal sendiri (Halim, 2015). Masalah yang paling esensial bagi setiap perusahaan adalah masalah struktur modal, karena baik dan buruk struktur modal mempunyai dampak terhadap posisi keuangan perusahaan.

Penelitian Danantio (2013) menyimpulkan bahwa struktur modal tidak berpengaruh secara signifikan terhadap nilai perusahaan, dan Ukuran perusahaan berpengaruh secara sifnifikan terhadap nilai perusahaan. Penelitian Cahyanti (2017) menyimpulkan bahwa struktur modal berpengaruh terhadap nilai perusahaan. Penelitian Sumartini,dkk (2016) menyimpulkan bahwa Ukuran perusahaan dan Struktur modal berpengaruh signifikan terhadap nilai perusahaan. Serta penelitian Abidin, dkk, (2014) menyimpulkan bahwa DER berpengaruh positif dan signifikan terhadap nilai perusahaan dan Size (ukuran perusahaan) berpengaruh positif dan tidak signifikan terhadap nilai perusahaan.

Berdasarkan hasil penelitian terdahulu terdapat hasil penelitian yang tidak konsisten terkait pengaruh ukuran perusahaan dan struktur modal terhadap nilai perusahaan. Sehingga peneliti menambahkan satu variabel lagi dalam penelitian ini yaitu dewan komisaris independen sebagai variabel moderasi, yang dapat memperkuat ataupun memperlemah pengaruh ukuran perusahaan dan struktur modal terhadap nilai perusahaan. Penelitian Abidin,dkk (2014) menyimpulkan bahwa ukuran perusahaan dan struktur modal berpengaruh positif terhadap nilai perusahaan.

Berdasarkan penjelasan diatas dan adanya hasil yang tidak konsisten dari penelitian sebelumnya, maka dalam penelitian ini peneliti ingin menguji pengaruh dari ukuran perusahaan dan struktur modal terhadap nilai perusahaan dengan dewan komisaris independen sebagai variabel moderasi.

\section{TINJAUAN PUSTAKA}

\section{Grand Theory}

Teori yang digunakan dalam penelitian ini yaitu agency theory (teori keagenan). Teori agensi menyebutkan bahwa agen lebih mementingkan dirinya sendiri untuk mendistribusikan investasi, dari yang tidak meningkatkan nilai perusahaan sehingga menjadi alternatif investasi yang lebih menguntungkan, Susanti (2010).

\section{Nilai Perusahaan}

Nilai perusahaan menurut Abdul Noerirawan (2012) merupakan kondisi dimana perusahaan mendapatkan gambaran kepercayaan dari masyarakat terhadap 
Karolina Yunita Dir, Pengaruh Ukuran Perusahaan Dan Struktur Modal Terhadap Nilai

Perusahaan Dengan Dewan Komisaris Independen Sebagai Variabel Moderasi

perusahaan dengan menjalani mekanisme aktivitas dalam beberapa tahun, yaitu sejak perusahaan itu dibangun hingga saat ini.

\section{Ukuran Perusahaan}

Ludhfiana Rahayu (2014) menyatakan bahwa semakin besar total asset maupun penjualan maka akan semakin besar pula ukuran sebuah perusahaan. Ukuran perusahaan merupakan cara yang dapat menguraikan perusahaan dengan berbagai cara yaitu dengan melihat total asset, jumlah penjualan, jumlah tenaga kerja dan lain-lain.

\section{Struktur Modal}

Menurut Halim (2015) struktur modal merupakan perbandingan antara total utang (modal asing) dengan total modal sendiri. Apabila sebuah perusahaan ingin mengembangkan perusahaannya maka perusahaan tersebut harus memiliki sebuah modal, dimana modal yang didapatkan tersebut bisa dengan cara berutang.

\section{Dewan Komisaris Independen}

Dewan komisaris independen dapat melakukan pengontrolan dan memberikan saran kepada direksi secara rasional, dengan adanya pengontrolan tersebut maka akan berpengaruh terhadap penigkatan capaian direksi sehingga dapat meningkatkan nilai perusahaan.

\section{Pengaruh Ukuran Perusahaan terhadap Nilai perusahaan}

Ukuran perusahaan berpengaruh terhadap nilai perusahaan, karena besar kecilnya ukuran perusahaan dapat mempengaruh minat investor. Pernyataan ini didukung oleh penelitian Danantio (2013) menyimpulkan bahwa ukuran perusahaan berpengaruh secara signifikan terhadap nilai perusahaan, dan penelitian Cahyanti (2017) menyimpulkan bahwa secara signifikan ukuran perusahaan berpengaruh terhadap nilai perusahaan. Dipihak lain penelitian Abidin, dkk (2014) bertolak belakang dengan hasil penelitian diatas, dalam penelitiannya menyimpukan bahwa ukuran perusahaan berpengaruh positif dan tidak signifikan terhadap nilai perusahaan. Berdasarkan uraian diatas hipotesis pertama dalam penelitian ini ditentukan sebagai:

$\mathrm{H}_{1}$ : Ukuran perusahaan secara parsial berpengaruh terhadap nilai perusahaan

\section{Pengaruh Struktur Modal terhadap Nilai Perusahaan}

Baik buruknya struktur modal dapat mempengaruhi posisi laporan keuangan perusahaan. Pernyataan ini didukung oleh penelitian Cahyanti (2017) Struktur modal berpengaruh terhadap nilai perusahaan, Sumartini,dkk (2016) Struktur modal berpengaruh signifikan terhadap nilai perusahaan. Di pihak lain Meythi, dkk (2012) bertolak belakang dengan hasil penelitian tersebut, dalam penelitiannya Meythi dkk menyimpulkan struktur modal tidak berpengaruh terhadap nilai perusahaan. Berdasarkan uraian tersebut hipotesis kedua dalam penelitian ini ditentukan sebagai berikut:

$\mathrm{H}_{2}$ : Ukuran perusahaan secara parsial berpengaruh terhadap nilai perusahaan

\section{Pengaruh Ukuran Perusahaan terhadap Nilai Perusahaan dengan Dewan Komisaris Independen sebagai Variabel Moderasi}

Dalam penelitian Sihwahjoeni (2012) Good Corporate Governance berpengaruh signifikan terhadap ukuran perusahaan. Selanjutnya dalam penelitian Danantio (2013) Good Corporate Governance (kepemilikan manajerial dan kepemilikan institutional) tidak memiliki pengaruh yang signifikan terhadap nilai perusahaan. Berdasarkan uraian tersebut hipotesis ketiga dalam penelitian ini ditentukan sebagai berikut: 
Karolina Yunita Dir, Pengaruh Ukuran Perusahaan Dan Struktur Modal Terhadap Nilai

Perusahaan Dengan Dewan Komisaris Independen Sebagai Variabel Moderasi

$\mathrm{H}_{3}$ : Dewan komisaris independen tidak memperkuat pengaruh ukuran perusahaan terhadap nilai perusahaan.

Pengaruh Struktur Modal Terhadap Nilai Perusahaan dengan Dewan Komisaris Independen sebagai Variabel Moderasi

GCG dapat menurunkan cost of capital sebagai dampak dikelolanya perusahaan secara sehat dan bertanggung jawab untuk meningkatkan nilai saham perusahaan serta menciptakan dukungan stakeholders terhadap perusahaan. Dalam penelitian Danantio (2013) Good Corporate Governance (kepemilikan manajerial dan kepemilikan institutional) tidak memiliki pengaruh yang signifikan terhadap nilai perusahaan, dewan komisaris independen berpengaruh signifikan terhadap nilai perusahaan. Sedangkan dalam penelitian Rahadian (2014) Good Corporate Governance (ukuran dewan direksi, komisaris independen, dan remunerasi) tidak berpengaruh signifikan terhadap struktur modal. Berdasarkan uraian tersebut hipotesis keempat dalam penelitian ini ditentukan sebagai berikut:

$\mathrm{H}_{4}$ : : Dewan komisaris independen memperkuat pengaruh struktur modal terhadap nilai perusahaan

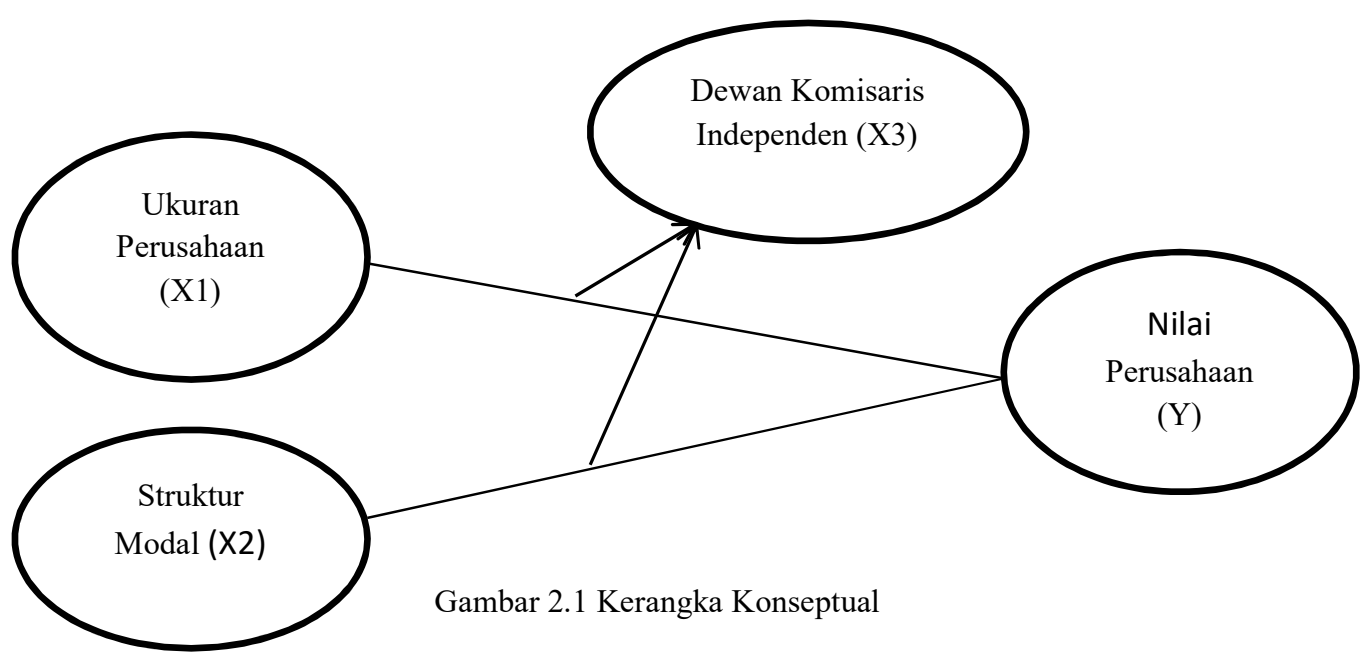

\section{METODE PENELITIAN}

Jenis data yang digunakan dalam penelitian ini yaitu data sekunder berupa laporan keuangan perusahaan perbankan yang terdaftar di bursa efek indonesia periode 2016-2017. Data dikumpulkan dengan cara mengakses dokumen laporan keuangan perusahaan perbankan yang terdaftar di BEI tahun 2016-2017 ke www.idx.co.id melalui internet, dengan total perusahaan 43 perusahaan.

Teknik pengambilan sampel dalam penelitian ini menggunakan purposive judgment sampling, yang merupakan penentuan sampel dengan kriteria-kriteria sebagai berikut, yaitu Perusahaan perbankan yang terdaftar di BEI pada tahun 2016-2017, Perusahaan perbankan yang mempublikasikan laporan keuangan secara berturut-turut pada tahun 2016-2017 di BEI. 3) Perusahaan perbankan yang tidak memiliki laporan dewan komisaris independen pada tahun periode 2016-2017. Berdasarkan kriteria diatas, perusahaan yang memenuhi kriteria dan dijadikan sampel penelitian yaitu sebesar 39 perusahaan. 
Karolina Yunita Dir, Pengaruh Ukuran Perusahaan Dan Struktur Modal Terhadap Nilai

Perusahaan Dengan Dewan Komisaris Independen Sebagai Variabel Moderasi

\section{Definisi operasional dan pengukuran variabel}

Variabel dependen yang dalam penelitian ini yaitu nilai perusahaan dan disimbolkan dengan "Y". Ukuran yang digunakan yaitu menggunakan Tobin's Q. Rumus Tobin's Q menurut Smithers dan Wright (2007) sebagai berikut:

$$
\mathrm{Q}=(\mathrm{MVE}+\mathrm{D}) / \mathrm{TA}
$$

Keterangan :

$\mathrm{MVE}=\mathrm{P} \times Q_{\text {shares }}$

$\mathrm{D}=$ Total Liabilitas + AVLTD

a. Market to Book Value of Equity merupakan nilai pasar dari jumlah lembar saham yang beredar.

b. Debt (D) merupakan besarnya nilai pasar utang, dimana nilai ini dapat dihitung dengan :

1) Total Liabilitas

2) AVLTD (Current Assets) yang terdiri dari Kas, Piutang Usaha, dan Persediaan.

3) Total Asset (TA) merupakan jumlah total aset perusahaan.

Variabel independen dalam penelitian ini adalah ukuran perusahaan (X1) dan struktur modal (X2).

\section{Ukuran Perusahaan}

Dalam penelitian ini ukuran perusahaan diukur dengan logaritma dari total asset yang dimiliki perusahaan. Hal ini disebabkan karena besarnya total asset masing-masing perusahaan berbeda bahkan mempunyai selisih yang besar, sehingga dapat menyebabkan nilai yang ekstrim. Rumus yang digunakan untuk mengukur ukuran perusahaan adalah:

\section{Struktur Modal}

SIZE= LOG Total Asset

Struktur modal merupakan perbandingan antara total utang (modal asing) dengan total modal sendiri/ekuitas (Halim, 2015). Debt to Equity Ratio (DER) digunakan untuk mengukur struktur modal. Menurut Kasmir (2010) DER adalah rasio yang mengukur sejauh mana besarnya hutang dapat ditutupi oleh modal sendiri, dengan rumus sebagai berikut:

Debt to Equity Ratio =

$$
\text { Total Utang (Debt) }
$$

$$
\text { Ekuitas (Equity) }
$$

Variabel moderasi dalam penelitian ini adalah dewan komisaris independen yang disimbolkan dengan "X3". Variabel moderasi adalah variabel independen lainnya yang dimasukkan ke dalam model, karena mempunyai efek kontingensi dari hubungan variabel dependen dan variabel independen sebelumnya (Jogiyanto, 2007). Dewan komisaris independen dihitung dengan rumus menurut (AS Puspitasari, 2014):

$$
D K I=\frac{\text { Jml Dewan Komisaris Independen }}{\text { Jml Dewan Komisaris Perusahaan }}
$$




\section{Teknik Analisis Data}

Dalam penelitian ini untuk teknik analisis datanya yaitu analisis regresi moderasian, yang digunakan untuk mengetahui bagaimana pengaruhn.antara variabel yang satu dengan variabel yang lain. Untuk menguji dan juga menjelaskan apakah variabel independen berpengaruh terhadap variabel dependen dengan variabel moderasi dalam penelitian ini, dapat menggunakan persamaan regresi yang diformulasikan oleh Jogiyanto (2007) sebagai berikut:

$$
\mathrm{Y}=\beta_{0}+\beta_{1} \mathrm{X}_{1}+\beta_{2} \mathrm{X}_{2}+\beta_{3} \mathrm{X}_{3}+\beta_{4} \mathrm{X}_{1} * \mathrm{X}_{3}+\beta_{5} \mathrm{X}_{2} * \mathrm{X}_{3}+\mathrm{e}
$$

Keterangan:

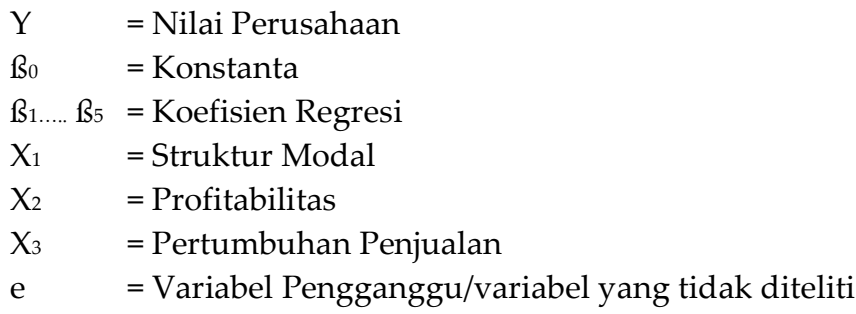

Analisis regresi yang digunakan dalam sebuah penelitian perlu dilakukan pengujian asumsi klasik. Dimana asumsi klasik ini adalah suatu pengujian hipotesis yang digunakan suatu penelitian yang menunjukkan model regresi tersebut apakah layak atau tidak untuk dilakukan ke pengujian selanjutnya.

\section{Uji Multikolinieritas}

Uji multikolinieritas bertujuan untuk menguji apakah model regresi ditemukan adanya kolerasi antar variabel independen (Ghozali, 2011). Model regresi yang baik seharusnya tidak terjadi korelasi diantara variabel independen agar tidak terdapat problem multikolinieritas. Untuk mengetahi ada tidaknya problem multikolinieritas dengan menentukan nilai VIP (Variance inflation Faktor), apabila nilai VIF $<10$ atau nilai Tolerance $>0,1$ berarti tidak terjadi multikolinieritas.

\section{Uji Autokorelasi}

Uji autokorelsi bertujuan untuk menguji apakad dalam model regresi ada korelasi antara kesalahan pengganggu pada periode $t$ dengan kesalahan pengganggu pada periode sebelumnya. Dilakukan dengan uji Durbin Watson (DW), kriteria yang digunakan menurut Firdaus (2010) adalah nilai DW $=1,55-2,46$. Jika nilai Durbin Watson sesuai kriteria maka tidak terjadi autokorelasi.

\section{Uji Heteroskedastisitas}

Uji ini digunakan untuk menguji apakah model regresi terjadi ketidaksamaan variance dari residual satu pengamatan ke pengamatan lain (Ghozali, 2011). Model regresi yang baik tidak mendeteksi heteroskedastisitas, untuk mendeteksi heteroskedastisitas adalah dengan melihat grafik plot antara nilai prediksi variabel terikat (Dependen) yaitu SRESID dan nilai residualnya ZPRED. Kriterianya jika gambar scatterplot tidak membentuk suatu gambar tertentu maka tidak terjadi heteroskedastisitas.

\section{Uji Normalitas}

Uji normalitas bertujuan untuk menguji apakah dalam model regresi, variabel pengganggu atau residual memiliki distribusi normal (Ghozali, 2011). Untuk menguji apakah residual berdistribusi normal atau tidak, test statistik yang digunakan adalah Kolmogorov Smirnov. Normal tidaknya distribusi data dapat dilihat dari nilai Asymp Sig (2-tailed), jika nilai Asymp Sig (2-tailed) > dari alpa 0.05 atau 5\% maka variabel pengganggu berdistribusi normal. 
Karolina Yunita Dir, Pengaruh Ukuran Perusahaan Dan Struktur Modal Terhadap Nilai

Perusahaan Dengan Dewan Komisaris Independen Sebagai Variabel Moderasi

\section{Pengujian Hipotesis}

Untuk menguji hipotesis yang diajukan maka digunakan Uji t untuk menguji dan menjelaskan apakah variabel independen secara parsial dapat berpengaruh terhadap nilai variabel dependen. Selanjutnya digunakan juga untuk menguji dan menjelaskan apakah variabel moderasi memoderasi hubungan antara variabel independen dengan variabel dependen. Apabila hasi uji $\mathrm{t}$ menunjukkan sig $\mathrm{t}<0,05$ maka hipotesis yang diajukan diterima. Sebaliknya jika hasil uji t menunjukkan > 0,05 maka hipotesis yang diajukan ditolak (Ghozali, 2011). Pada variabel moderasi, jika beta menunjukkan angka positif maka variabel moderasi memperkuat pengaruh variabel independen terhadap variabel dependen, sebaliknya jika beta menunjukkan angka negatif maka variabel moderasi memperlemah pengaruh variabel independen terhadap variabel dependen (Jogiyanto, 2007).

\section{HASIL PENELITIAN}

\section{Uji Asumsi Klasik}

\section{Uji Multikolinieritas}

Hasil uji asumsi klasik multikolinieritas dengan menggunakan pendekatan VIF (Variance Inflation Faktor) menunjukkan bahwa nilai VIF untuk variabel $\mathrm{x} 1$, x2 dan $\times 2{ }^{*} \times 3$ kurang dari 10 dan nilai Tolerance lebih dari 0,1. Sedangkan x3 dan x1*x3 nilai VIF lebih dari 10 dan nilai Tolerance lebih dari 0,1 sehingga yang tidak terjadi multikolinieritas hanya 3 variabel saja dan 2 variabel lainnya terjadi. Hal ini terjadi karena adanya perhitungan antara variabel.

\section{Uji Autokorelasi}

Hasil uji asumsi klasik autokorelasi menunjukkan bahwa nilai Durbin Watson sebesar 2.073 terletak diantara 1,55 - 2,46. Hal tersebut mengindikasikan bahwa tidak terjadi autokorelasi.

\section{Uji Heteroskedastisitas}

Hasil uji asumsi klasik heteroskedastisitas menunjukkan bahwa pada gambar scatterplot tidak membentuk suatu gambar/pola tertentu, sehingga dengan demikian tidak terjadi heteroskedastisitas.

\section{Uji Normalitas}

Hasil uji asumsi klasik normalitas menunjukkan bahwa nilai Asymp Sig (2-tailed) untuk varibel $x 1, x 2, x 1^{*} \times 3$ dan $x 2^{*} x 3$ melebihi 0.05 , sedangkan untuk variabel $x 3$ kurang dari 0,05 hal ini menunjukkan bahwa $\times 3$ dalam penelitian ini tidak dapat berpengaruh terhadap variabel $\mathrm{Y}$ dan tidak dapat memoderasi antara variabel independen dengan variael dependen.

\section{Hasil Analisis Regresi Moderasian}

Hasil analisis regresi moderasian dapat dibuat pesamaan regresi sebagai berikut:

$Y=\beta_{0}+\beta_{1} X_{1}+\beta_{2} X_{2}+\beta_{3} X_{3}+\beta_{4} X_{1} X_{3}+\beta_{5} X_{2} X_{3}+e$

$Y=-613.683+0.750 X 1+(-1.068) X 2+3.832 X 3+(-4.409) X 1 . X 3+0.917 X 2 . X 3+e$

Diringkas pada tabel berikut ini:

Tabel 1 Hasil Analisi Regresi Moderasian

\begin{tabular}{|l|c|c|c|}
\hline Variabel & $\begin{array}{l}\text { Koefisisen regresi yang } \\
\text { sudah di standarisasi }\end{array}$ & $\begin{array}{l}\text { Nilai } \\
\text { signifikasi }\end{array}$ & Kesimpulan \\
\hline Variabel X1 (ukuran perusahaan) & 0.750 & 0.016 & Berpengaruh \\
\hline Variabel X2 (Struktur Modal) & -1.068 & 0.000 & Berpengaruh \\
\hline $\begin{array}{l}\text { Variabel X3 (Dewan Komisaris } \\
\text { Independen) }\end{array}$ & 3.832 & 0.024 & Berpengaruh \\
\hline Variabel X1*X3 & -4.409 & 0.013 & Berpengaruh \\
\hline Variabel X2*X3 & 0.917 & 0.005 & \\
\hline Nilai R-square $=0.261$ &
\end{tabular}


Karolina Yunita Dir, Pengaruh Ukuran Perusahaan Dan Struktur Modal Terhadap Nilai

Perusahaan Dengan Dewan Komisaris Independen Sebagai Variabel Moderasi

Berdasarkan persamaan regresi dari tabel 4.10 di atas maka dapat dijelaskan sebagai berikut:

1. Koefisien regresi $($ beta $=ß)$ yang digunakan dalam penelitian ini adalah koefisien regresi (beta $=ß$ ) yang sudah terstandarisasi. Menurut Solimun (2011) bahwa jika data yang diamati memiliki satuan yang berbeda, maka di transformasi menjadi data standardize. Dalam penelitian ini untuk variabel dependennya yaitu Nilai Perusahaan menggunakan satuan rupiah, sedangkan untuk variabel dependennya yaitu ukuran perusahaan dan struktur modal serta variabel moderasinya yaitu dewan komisaris independen menggunakan rasio.

2. Koefisien regresi (beta $=\S$ ) yang sudah di standarisasi atas variabel ukuran perusahaan (X1) bertanda positif 0.750. Hal tersebut menunjukan bahwa variabel ukuran perusahaan berpengaruh terhadap variabel nilai perusahaan. Dengan artian jika nilai ukuran perusahaan dinaikan 1 satuan, maka variabel nilai perusahaan tepat akan dinaikan 0.750 satuan.

3. Koefisien regresi (beta $=\S$ ) yang sudah di standarisasi atas variabel struktur modal (X2) bertanda negatif -1.068. Hal tersebut menunjukan bahwa variabel struktur modal berpengaruh negatif terhadap variabel nilai perusahaan. Dengan artian jika nilai struktur modal dinaikan 1 satuan, maka variabel nilai perusahaan akan turun 1.068 satuan. Dengan asumsi variabel lain tidak berubah.

4. Koefisien regresi (beta $=\S$ ) yang sudah di standarisasi atas variabel moderasi (X1.X3) bertanda negatif -4.409. Hal ini menunjukan bahwa variabel moderasi (interaksi ukuran perusahaan - dewan komisaris independen) berhubungan negatif variabel nilai perusahaan. Dengan artian jika variabel X1.X3 dinaikan 1 satuan, maka nilai dari nilai perusahaan akan turun 4.409 satuan.

5. Koefisien regresi (beta=ß) yang sudah di standarisasi atas variabel moderasi (X2.X3) bertanda positif 0.917. Hal ini menunjukan bahwa variabel moderasi (interaksi struktur modal-dewan komisaris independen) berhubungan positif dengan variabel nilai perusahaan. Dengan artian jika variabel X2.X3 dinaikan 1 satuan, maka nilai dari nilai perusahaan tepat akan dinaikan 0.917 satuan.

6. Nilai R-square 0.261, menunjukan bahwa perubahan variabel nilai perusahaan yaitu 26.1 persen dipengaruhi oleh variabel ukuran perusahaan, struktur modal dan dewan komisaris independen. Sedangkan untuk sisanya yaitu 73.9 pesen dipengaruhi oleh variabel lain yang tidak diteliti.

\section{Hasil Uji Hipotesis Pertama}

Hasil hipotesis pertama pada penelitian ini dapat disajikan pada tabel 4.15 yang sudah diringkas diatas, nilai signifikasin uji-t atas variabel ukuran perusahaan sebesar 0.016 lebih kecil dari alpa 0.05 atau 5\%. Hal tersebut berarti secara parsial variabel ukuran perusahaan berpengaruh terhadap variabel nilai perusahaan. Sehingga hipotesis pertama yang menyatakan bahwa ukuran perusahaan berpengaruh terhadap nilai perusahaan diterima.

\section{Hasil Uji Hipotesis Kedua}

Hasil hipotesis kedua pada penelitian ini dapat disajikan pada tabel 4.15 yang sudah diringkas diatas, nilai signifikasin uji-t atas variabel ukuran perusahaan sebesar 0.000 lebih kecil dari alpa 0.05 atau $5 \%$. Hal tersebut berarti secara parsial variabel struktur modal berpengaruh terhadap variabel nilai perusahaan. Sehingga hipotesis kedua yang menyatakan bahwa struktur modal berpengaruh terhadap nilai perusahaan diterima.

\section{Hasil Uji Hipotesis Ketiga}


Karolina Yunita Dir, Pengaruh Ukuran Perusahaan Dan Struktur Modal Terhadap Nilai Perusahaan Dengan Dewan Komisaris Independen Sebagai Variabel Moderasi

Hasil hipotesis ketiga pada penelitian ini dapat disajikan pada tabel 4.15 yang sudah diringkas diatas, nilai signifikasin uji-t atas variabel dewan komisaris independen sebesar 0.013 lebih besar dari alpa 0.05 atau 5\%. Hal tersebut berarti variabel dewan komisaris independen memoderasi pengaruh variabel ukuran perusahaan terhadap variabel nilai perusahaan. Sedangkan koefisien regresi (beta= $ß$ ) yang sudah distandarisasi atas variabel dewan komisaris independen bernilai -4.409 dan bertanda negatif, dengan demikian dapat diartikan bahwa variabel dewan komisaris independen tidak memperkuat pengaruh variabel ukuran perusahaan terhadap variabel nilai perusahaan. Sehingga hipotesis ketiga yang menyatakan bahwa dewan komisaris independen tidak memperkuat pengaruh ukuran perusahaan tehadap nilai perusahaan diterima.

\section{Hasil Uji Hipotesis Keempat}

Hasil hipotesis kelima pada penelitian ini dapat disajikan pada tabel 4.14 yang sudah diringkas diatas, nilai signifikasin uji-t atas variabel dewan komisaris independen sebesar 0.005 lebih kecil dari alpa 0.05 atau 5\%. Hal tersebut berarti variabel dewan komisaris independen memoderasi pengaruh variabel struktur modal terhadap variabel nilai perusahaan. Sedangkan koefisien regresi (beta=ß) yang sudah distandarisasi atas variabel dewan komisaris independen bernilai 0.917 dan bertanda positif, dengan demikian dapat diartikan bahwa variabel dewan komisaris independen memperkuat pengaruh variabel struktur modal terhadap variabel nilai perusahaan. Sehingga hipotesis keempat yang menyatakan bahwa dewan komisaris independen memperkuat pengaruh struktur modal tehadap nilai perusahaan diterima.

\section{PEMBAHASAN}

Hasil penelitian variabel ukuran perusahaan untuk nilai signifikan uji-t nya menunjukan bahwa sebesar 0.016 lebih kecil dari alpa 0.05 atau 5\% dengan koefisien regresi yang sudah distandarisasi sebesar 0.750 bertanda positif, maka ukuran perusahaan berpengaruh secara signifikan terhadap nilai perusahaan. Dengan demikian jika variabel ukuran perusahaan dinaikan 1 satuan, maka nilai variabel nilai perusahaan tepat akan naik 0.750 satuan. Hal ini mengindikasikan bahwa secara statistik jika besar kecilnya ukuran perusahaan akan berpengaruh terhadap nilai peusahaan. Hasil penelitian ini didukung dengan penelitian Danantio (2013) dan Chayanti (2017) yang menyatakan bahwa secara parsial ukuran perusahaan berpengaruh terhadap nilai perusahaan.

Hasil penelitian variabel struktur modal untuk nilai signifikan uji-t nya menunjukan bahwa sebesar 0.000 lebih kecil dari alpa 0.05 atau 5\% dengan koefisien regresi yang sudah distandarisasi sebesar -1.068 dan bertanda negatif. Maka jika variabel struktur modal dinaikan 1 satuan, maka kenaikan satuannya tidak akan berpengaruh terhadap variabel nilai perusahaan. Penelitian ini bertentangan dengan penelitian dari Chayanti (2017) dan Sumartini,dkk (2016) yang menyatakan bahwa struktur modal berpengaruh secara signifikan terhadap nilai perusahaan..

Hasil penelitian variabel moderasi (dewan komisaris independen-ukuran perusahaan) untuk nilai signifikan uji-t nya menunjukan bahwa sebesar 0.013 lebih kecil dari alpa 0.05 atau 5\% dengan koefisien regresi yang sudah distandarisasi sebesar -4.409 bertanda negatif. Maka jika variabel ukuran perusahaan dinaikan 1 satuan, maka nilai variabel nilai perusahaan akan turun $\quad-4.409$ satuan. Hal ini menunjukan bahwa dewan komisaris independen tidak memperkuat atau memoderasi pengaruh ukuran perusahaan terhadap nilai perusahaan. Penelitian ini bertentangan dengan penelitian Sihwahjoeni (2012).

Copyright @ JRMA 2019 ISSN. 2337-5663 
Karolina Yunita Dir, Pengaruh Ukuran Perusahaan Dan Struktur Modal Terhadap Nilai Perusahaan Dengan Dewan Komisaris Independen Sebagai Variabel Moderasi

Hasil penelitian variabel moderasi (dewan komisaris independen-struktur modal) untuk nilai signifikan uji-t nya menunjukan bahwa sebesar 0.005 lebih kecil dari alpa 0.05 atau 5\% dengan koefisien regresi yang sudah distandarisasi sebesar 0.917 bertanda positif. Maka jika variabel ukuran perusahaan dinaikan 1 satuan, maka nilai variabel nilai perusahaan juga akan naik 0.917 satuan. Hal ini menunjukan bahwa dewan komisaris independen memperkuat atau memoderasi pengaruh struktur modal terhadap nilai perusahaan. Penelitian ini didukung dengan penelitian Sihwahjoeni (2012).

\section{KESIMPULAN}

Hasil penelitian dan pembahasan dapat disimpulkan bahwa Secara parsial ukuran perusahaan berpengaruh terhadap nilai perusahaan, secara parsial struktur modal berpengaruh terhadap nilai perusahaan, dewan komisaris independen tidak memperkuat atau memoderasi pengaruh ukuran perusahaan terhadap nilai perusahaan, dan dewan komisaris independen memperkuat atau memoderasi pengaruh struktur modal terhadap nilai perusahaan.

Bagi perusahaan perbankan di Bursa Efek Indonesia agar lebih memperhatikan lagi terkait ukuran perusahaan, struktur modal dan pengawasan dewan komisaris independen dalam perusahaan. Bagi peneliti selanjutnya dalam penelitian ini hanya sebatas meneliti ukuran perusahaan, struktur modal, dewan komisaris independen dan nilai perusahaan. Disarankan bagi peneliti selanjutnya agar dapat menambah variabel lain seperti profitabilitas, pertumbuhan penjualan dan elemen lain dalam GCG agar dapat memperluas penelitian, menambahkan periode atau menambah sampel dalam penelitian selanjutnya dan lebih teliti lagi dalam mengambil judul terkait variabel moderasi. Penelititi selanjutnya disarankan juga agar tidak memakai variabel dewan komisaris independen sebagai variabel moderasi. Sebaiknya untuk dewan komisaris independenya dijadikan sebagai variabel regresi linear berganda biasa.

Dalam penelitian ini memiliki keterbatasan-keterbatasan yang dapat dijadikan pertimbangan bagi peneliti selanjutnya dalam meneliti variabel yang sudah peneliti teliti, adapun keterbatasannya adalah dalam penelitian ini hanya menggunakan variabel ukuran perusahaan dan struktur modal sebagai variabel independen, untuk periode yang digunakan hanya dua (2) tahun yaitu 2016-2017, sampel penelitian yang digunakan hanya 39 perusahaan untuk 2 periode, pada hasil uji asumsi klasik normalitas yang menggunakan moderasian untuk variabel dewan komisaris independen tidak berdistribusi normal, dan perhitungan hasil nilai R-squere pada penelitian ini hanya 15,5 $\%$ lebih banyak dari variabel lain yang tidak di teliti yaitu 84,5\%.

\section{DAFTAR PUSTAKA}

Abdul Muid, Moch. Roni Neorirawan. 2012. Pengaruh Faktor Internal dan Eksternal Perusahaan terhadap Nilai Perusahaan. Jurnal Akuntansi Vol.1 No.2 Hal.4.

Abidin, Zaenal., Meina Wulansari Yusniar \& Muhammad Ziyad. 2014 . Pengaruh Struktur Modal, Kebijakan Dividen dan Size Terhadap Nilai Perusahaan. Jurnal Wawasan Manajemen, Vol 2, Nomor 3, Oktober 2014.

AS, Puspitasari. 2014. Pengaruh Proporsi Dewan Komisaris Independen, Kepemilikan Manajerial dan Kepemilikan Institusional terhadap Pemberian Opini Audit Going Consern (Studi Kasus pada Perusahaan Manufaktur yang Terdaftar di Bursa Efek Indonesia Tahun 2010-2012). e-journal.uajy.ac.id

Agoes, Sukrisno dan Ardana, I Cenik. 2014. Etika Bisnis Dan Profesi Edisi Revisi. Salemba Empat. Jakarta

Copyright @ JRMA 2019 ISSN. 2337-5663 Hal | 10 
Karolina Yunita Dir, Pengaruh Ukuran Perusahaan Dan Struktur Modal Terhadap Nilai Perusahaan Dengan Dewan Komisaris Independen Sebagai Variabel Moderasi

Cahyanti, Yuli Tri. 2017. Pengaruh Struktur Modal dan Profitabilitas Terhadap Nilai Perusahaan dengan Pertumbuhan Penjualan Sebagai Variabel Moderasi (Studi Kasus pada Perusahaan Manufaktur yang Terdaftar di Bursa Efek Indonesia Tahun 2013-2015). Journal Riset Mahasiswa Akuntansi, Fakultas Ekonomika dan Bisnis Universitas Kanjuruhan, Malang.

Dewi, A. S. M. dan Ari, W. (2013). Pengaruh Struktur Modal, Profitabilitas dan Ukuran Perusahaan pada Nilai Perusahaan. E-Jurnal Akuntansi. ISSN: 2302-8556. Hal: 358372.

Danantio, Novan. 2013. Pengaruh Good Corporate Governance, Struktur Modal, ROE, dan Ukuran Perusahaan terhadap Nilai Perusahaan pada Perusahaan Manufaktur Yang Terdaftar Di BEI. Artikel Ilmiah, Prodi Akuntansi, Sekolah Tinggi Ilmu Ekonomi Perbanas Surabaya.

Firdaus, M. 2010. Ekonometrika Suatu Pendekatan Aplikatif. Jakarta: Bumi Aksara.

Ghozali, Imam. 2011. “Aplikasi Analisis Multivariate Dengan Program SPSS”. Semarang: Badan Penerbit Universitas Diponegoro.

Halim, Abdul. 2015. Manajemen Keuangan Bisnis: Konsep dan Aplikasinya. Jakarta: Mitra Wacana Media.

Horne, James C.Van dan John M.Machowicz Jr. 2010. Prinsip-Prinsip Manajemen Keuangan, Edisi 13. Jakarta: Salemba Empat.

Jogiyanto. 2007. Metodologi Penelitian Bisnis. Yogyakarta: BPFE.

Kasmir. 2010. Pengantar Manajemen Keuangan, Edisi Kedua. Jakarta: Prenadamedia Group.

Ludhfiana Rahayu Novia Sari. (2014). "Pengaruh Ukuran Perusahaan, Leverage dan Good Corporate Governance terhadap Kualitas Laporan Keuangan pada Perusahaan Manufaktur yang terdaftar di BEI tahun 2009-2012". Skripsi. Universitas Negeri Yogyakarta.

Meythi., Riki Martusa \& Debbianita. 2012. Pengaruh Struktur Modal Terhadap Nilai Perusahaan Dengan Pertumbuhan Perusahaan Sebagai Variabel Moderating. Disertasi, Program Pendidikan Profesi Akuntansi, Universitas Kristen Maranatha.

Rahadian, Andika. 2014. Pengaruh Good Corporate Governance Terhadap Struktur Modal Perusahaan (Studi Empiris pada Perusahaan Manufaktur yang Terdaftar di Bursa Efek Indonesia pada Tahun 2010-2012). Program Sarjana Fakultas Ekonomika dan Bisnis Universitas Diponegoro, Semarang.

Sartono, Agus. 2010. Manajemen Keuangan Teori dan Aplikasi. Yogyakarta: BPFEE.

Sumartini, Cipta Wayan \& Suwendra. 2016. Pengaruh Ukuran Perusahaan dan Struktur Modal Terhadap Nilai Perusahaan pada Perusahan Sektor Transportasi yang Terdaftar di Bursa Efek Indonesia. e-Journal Bisma Universitas Pendidikan Ganesha, Singaraja.Sihwahjoeni, 2012.Pengaruh Good Corporate Governance Terhadap Ukuran Perusahaan dan Dampaknya Terhadap Manajemen Laba.Fakultas Ekonomika. Universitas Merdeka Malang.

Smithers, Andrew dan Wright, Stephen. 2008. Valuing Wall Street, McGraw Hill.

Susanti, Rika. 2010. Analisis Faktor-Faktor Yang Berpengaruhi Terhadap Nilai Perusahaan. UNDIP. Semarang.

Copyright (C) JRMA 2019 ISSN. 2337-5663 Hal | 11 
Karolina Yunita Dir, Pengaruh Ukuran Perusahaan Dan Struktur Modal Terhadap Nilai Perusahaan Dengan Dewan Komisaris Independen Sebagai Variabel Moderasi

Solimun. 2011. Analisis Multivariat Pemodelan Struktural. Malang: CV: Citra

Sihwahjoeni, 2012.Pengaruh Good Corporate Governance Terhadap Ukuran Perusahaan dan Dampaknya Terhadap Manajemen Laba.Fakultas Ekonomika. Universitas Merdeka Malang.

www.idx.co.id 